\title{
Usable elements of technical infrastructure around historic architecture in the Old Town of Prague
}

\author{
Katarzyna Gładyszewska-Fiedoruk ${ }^{1, *}$, and Dorota Anna Krawczyk $^{1}$ \\ ${ }^{1}$ Bialystok University of Technology, Department of HVAC Engineering, 15-351 Bialystok, Poland
}

\begin{abstract}
Utilizable architectural details can highlight the character of a historical building, but they can also change the perception of the total view of this particular building or even the whole district. That is why architectural elements installed in old buildings or old, historical quarters are a challenge for designers and contractors. It is possible to achieve a good and well-accepted effect, but one condition must be abided - the investor must try to get all elements harmonized. The elaboration of a concept requires a good knowledge about both building history and detail character. The paper shows an application of engineering elements in the Old Town of Prague. The research was conducted in the historical part of Prague, where even on the first look you can see scrupulousness about all elements of buildings, the most useful elements related to urban networks and object furnishings are not incompatible with the historic character of the city. A widespread public debate on renovation of constructions, showing good and bad examples of retrofitting, would allow avoiding common mistakes and link modernity with historical value.
\end{abstract}

\section{Introduction}

Architectural aesthetic problems such as unpleasing forms, shapes, and styles which create disordered environments have influenced cities visually, mentally and psychologically for centuries 1 . An architectural detail is usually a part of the whole building even though it does not exist as an separate item, so it is therefore assumed that it is an inseparable part of the whole construction. However, an architectural detail is often seen as an independent thing. Perhaps this is related to the broad definition of an architectural element, which states that they are the unique details and component parts that, together, form the architectural styles of houses, buildings and structures. Perception and understanding of the architectural element is related to the size of the object, the scale of the object and of course the distance between the viewer and the element. The concept of an architectural detail is often compared to a construction or an architectural element. Sometimes these are synonymous with each other, but in many situations they differ. This paper's aim is the discussion on some installation details of utility constructions which are also usable architectural details woven into the historic district of Prague - in the Czech capital.

\footnotetext{
*Corresponding author: k.gladyszewska@pb.edu.pl
} 
A utility element can highlight an architectural detail, but it can also change the perception of the building or area 2 around the object thereby influencing the environment.

The most complicated situation is adding new, modern elements and technologies to an existing area, which has not changed for centuries. These elements of modern systems are proposed to help building users in everyday life 3. Currently most of the new installations, corresponding to contemporary needs like cold and warm water or television infrastructure elements, are positively perceived by the users. The old town with a sewage system is much better rated than the gutters, even though they came from the same buildings. Most people agree that satellite dishes make their life easier and nicer so they are a sign of the changing times, and although they do not fit into ancient walls and roofs they are accepted 4.

Many people have discussed architectural details to show how design features influence impressions of a building facade. These subjective impressions of a detail could be predicted by an objective measurement based solely on physical properties of environments 5 . Another paper 6 showed dramatic changes in the residential environment during the postsocialist transition to Prague city centre parts: the historical core, which has been exposed to massive tourism and commercialization 6 . While the historical cores of the post-socialist cities of Central and Eastern Europe are adapting to the invasion of tourism and profitable companies, dynamic regeneration is altering the character of the inner-city. Changing residential environments, landscapes and functions affect the daily lives and residential satisfaction of the local population.

Urban design ideologies have gained ground as a planning strategy, and the historic town has, to an increasing degree, become the model for the transformation of cities and changes in the mentality of the people. Simultaneously the functional requirements of streets have become more complex. Currently the importance of the street as an architectural element seems incompatible with its function as a versatile transport artery 7 . Changes in the nature of environmental planning in Prague were shown in 8 , although according to the author, the role and effectiveness of planning is still open, because all factors should be taken into account: the environmental pollution, the historic core and the suburban greenspace. In future planning, there is a need to be able to facilitate investment in new developments and rehabilitation of old town's parts without allowing for the freedom of the market to damage the environment and heritage 8 . The research was conducted in the historical part of Prague to show how new elements are combined with the historic character of the city.

\section{The history of The Old Town in Prague}

Prague is the capital and the largest city of the Czech Republic. It is also one of the oldest cities, located in the central part of the country on the Vltava River. Prague is an administrative, industrial, academic and cultural center having an international importance.

The first inhabitants of this area on the Vltava river, who started to settle here about $500 \mathrm{BC}$, were Celtic tribes. They were gradually displaced by the incoming Germanic people between IX and VI century BC. The first Slavic tribes arrived in the area about $500 \mathrm{AD}$. After years of battles for supremacy, about $800 \mathrm{AD}$ the Přemyslid dynasty came to power and established the city. From 973 AD, Prague was the headquarters of the first bishopric in these areas. The city enlarged during the reign of Charles IV, who set up the first university in Central Europe - Carolinum. The new part of Prague (New Town) allowed it to became the largest city in Europe. In 1620, Prague as the capital of the Kingdom of Bohemia lost its importance and for many years remained in the shadow of Vienna. Current Prague was founded in 1784 from five previously independent but interrelated cities located in the neighborhoods whose origins are dated to the Middle Ages: 
the Old Town, New Town, Josefov, Mala Strana and Prague Castle, which has always been the abode of Czech sovereigns. Since 1992, the historic center has been a UNESCO World Heritage Site. Due to the wealth of attractions, Prague is one of the most visited cities in Europe. Some of the tourist attractions are the New Town with its castle and Gothic cathedral, St. Vitus, St. Wenceslas, St. Adalbert, Charles Bridge over the Vltava River, Golden Lane, Malá Strana - full of churches, palaces, gardens and picturesque streets, (already mentioned), Loreta, and Old Town on the right bank of the Vltava River.

At the end of the nineteenth century a large number of representative buildings were constructed and this allowed Prague to be a significant city again. In 1918, Prague became the capital of the newly formed Czechoslovakia. In the years 1939-1945 it was occupied by the Third Reich, and then released in 1945. In 1993, after the division of Czechoslovakia into two parts, the city became the capital of the Czech Republic.

All these changes contributed the Prague architecture and technological improvements influenced the architectural details and buildings in the Old Town 6.

\section{The examples of architectural and technical elements in the old town}

In new urban areas antennas, air conditioning units or gas pipes are normal and nobody is surprised by seeing them, but the same equipment in the historical part of the city looks strange. Nowadays, most of new technologies have to be integrated into buildings which had been built earlier and it is not easy to imagine people living without them. Some papers showed the concept of no-architectural details which could be divided into five categories:

- Lighting 9, 10,

- Antennas,

- Air conditioning systems 2 ,

- Elements of network (water, sewage, das, telecommunication etc.),

- Others (for systems outdoor blinds, garbage cans or city monitoring camera) 11.

\subsection{Lighting}

Fig. 1 and 2 present the street lamps in the Old Town of Prague. Fig. 1 shows the lamp-post and Fig. 2 a wall lantern, both corresponding to the age of surrounding buildings.

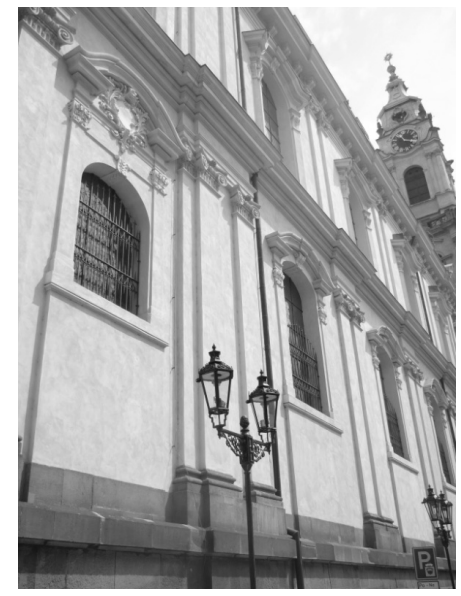

Fig. 1. The street lamp [Source: authors].

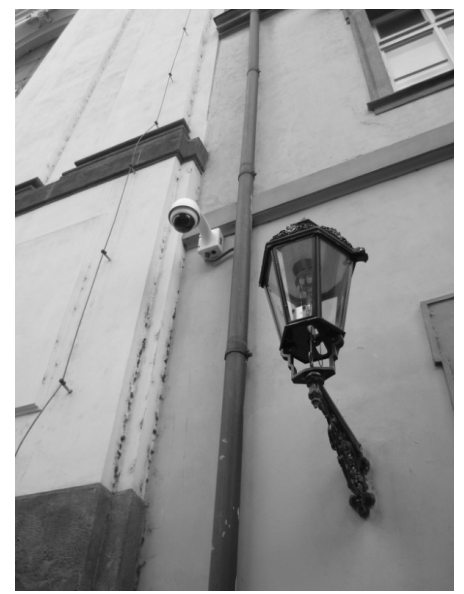

Fig. 2. The street lamp on the building's wall [Source: authors]. 
Near the lamp, a completely modern street camera and gutter were installed but they are not very noticeable.

Although the contemporary elements create dissonance with the historic building, it does not offend the aesthetic feel of most tourists (according to the survey made on the street, $85 \%$ of the tourists did not notice modern elements in this place). The authors, however, point out that it would be better to replace the modern gutter with another one made from a material and style that would be consistent with the building.

\subsection{Antennas}

Fig. 3 shows different types of antennas (broadcast and television) installed on buildings' roofs. They are evidence of changing technology and equipment of buildings. The antennas do not disfigure the view but they also do not harmonize with the historical objects.

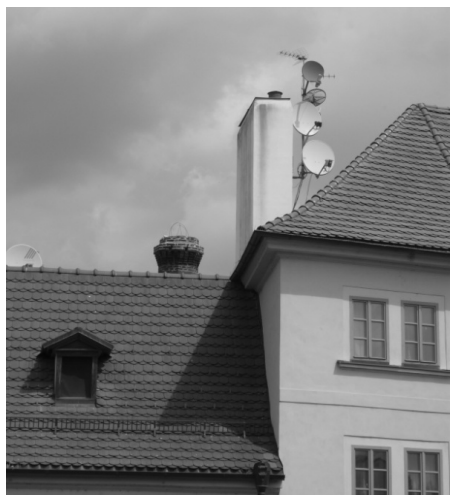

Fig. 3. The broadcast and television antennas on the roofs of buildings located in the Old Town [Source: authors].

\subsection{Air conditioners}

The air conditioning systems are more and more popular, especially in public buildings like hotels or restaurants and most of often it is not possible to install them in a place they are not seen.

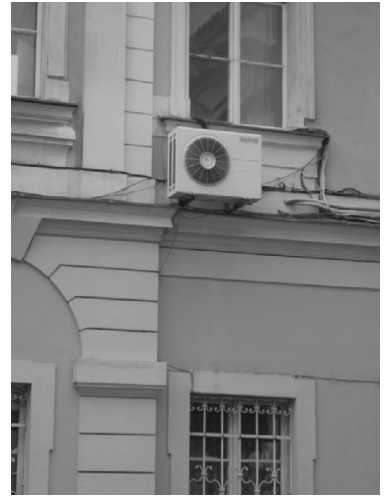

Fig. 4. The outside unit of air conditioning system [Source: authors].

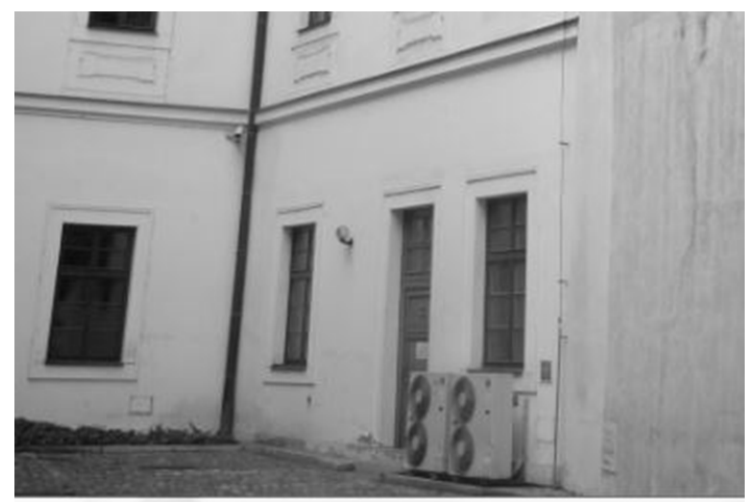

Fig. 5. The outside unit of air conditioning system [Source: authors]. 
The outside units are mostly located on external walls (fig. 4, 5). Their size is quite large and they are easily seen by the buildings' users and tourists. It is a big problem of most towns all over Europe. Fig. 5 also shows the camera and a lightning rod located near the gutter.

\subsection{Elements of the city network}

The elements of the outer network are mostly really well integrated with historical places, for instance manholes of heat distribution and a water-pipe network or sewage system (fig. 6, 7).

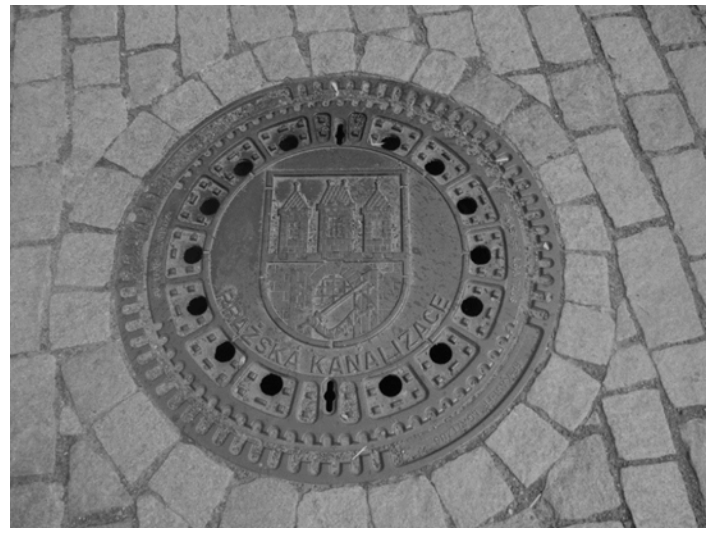

Fig. 6. The manhole of sewage system [Source: authors].

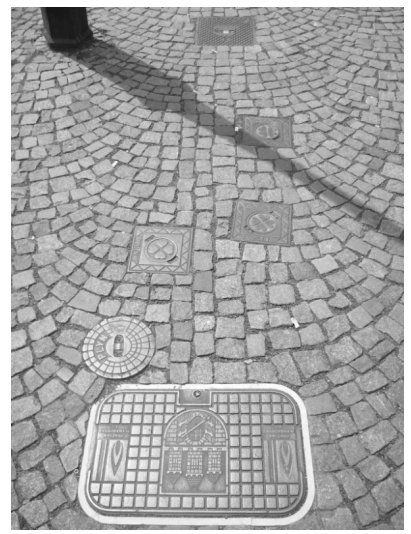

Fig. 7. The manholes of different networks [Source: authors].

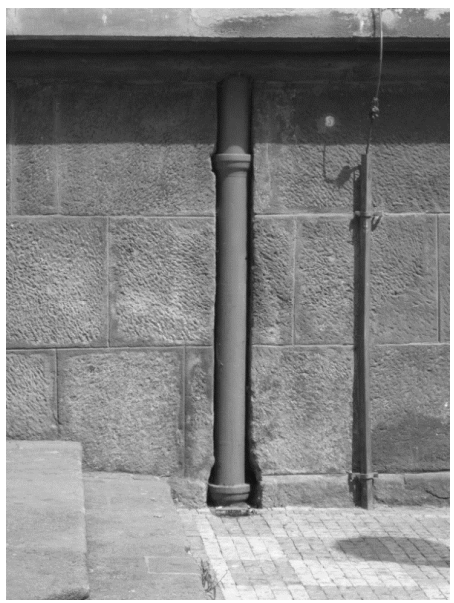

Fig. 9. The new gutter in a color quite dissonant to walls [Source: authors].

Fig. 8. The stylish gutter [Source: authors].

Some examples of gutters show that it is possible to make them stylish (fig. 8), although not everyone cares about it (fig. 2, 9).

An interesting way to disguise the ventilation outside air inlet opening is shown in fig. 10. The commercial restaurant is located there so it is an element which is of interest to pedestrians and fills the role of an advertisement.

One of the most important systems is a water fire network, especially in old, historical parts of towns, so also in Prague you can see some elements of this system (fig. 11-13). 


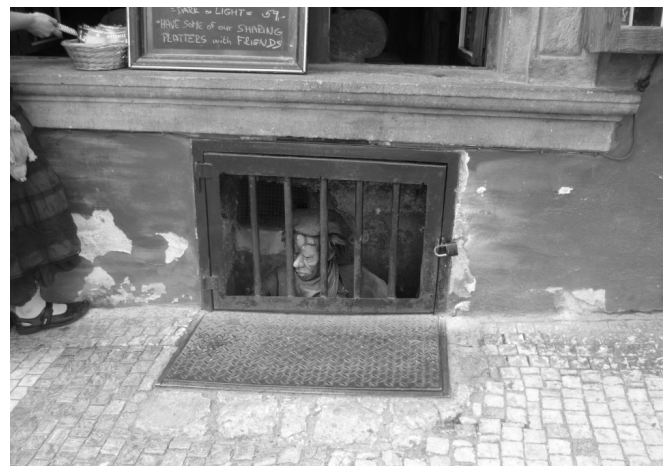

Fig. 10. The ventilation outside air inlet opening [Source: authors].

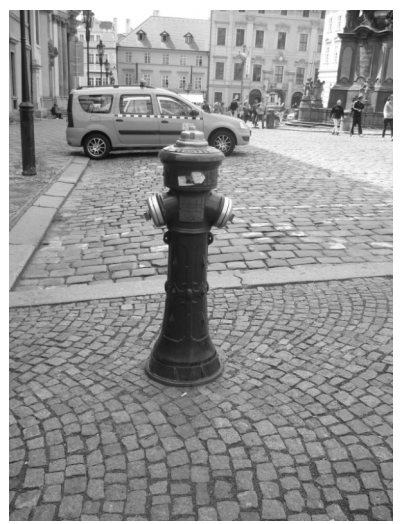

Fig. 11. The fire hydrant on the Old Town of Prague [Source: authors].

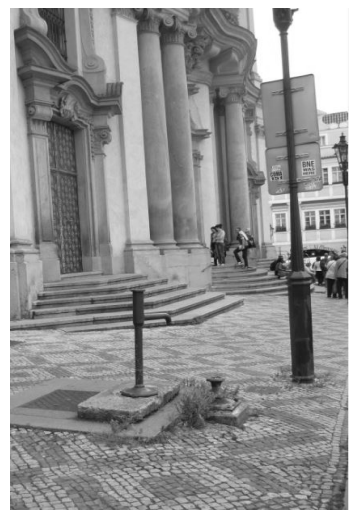

Fig. 12. The street water pump [Source: authors].

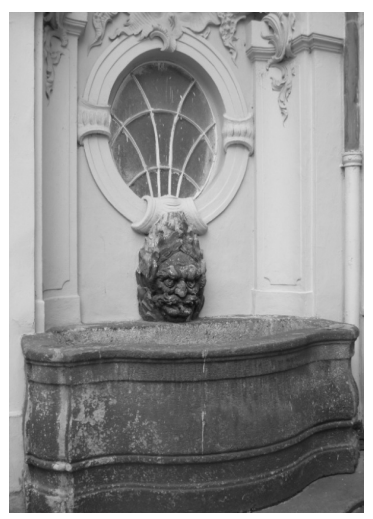

Fig. 13. The stylish waterworks in the courtyard, used also as a water basin in case of fire [Source: authors].

\subsection{The other elements}

Authors decided to show the form of garbage (fig. 14) located in the Old Town, because in general, it was not an architectural element corresponding to the nature of the city. Other historic places 8 take better care about the shape and form of garbage. 


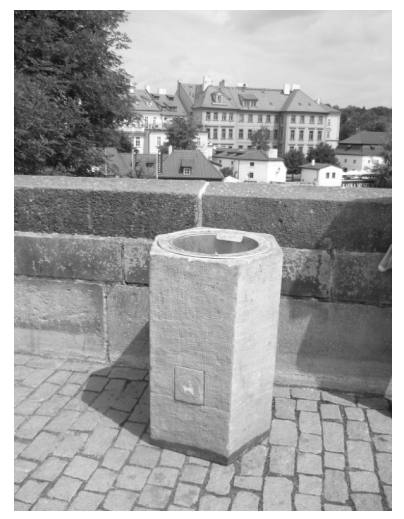

Fig. 14. The garbage receptacle on the Karol Bridge [Source: authors].

\section{Conclusions}

Architectural elements are the part of the architectural language, which changes and enriches with new elements, to fit into the time it is used. Modern details are strongly embedded in the world of technology, adjusting to contemporary developments and needs. Architectural elements use new technologies and materials to participate in the creation of a spatial form 12. It should be noted that in the historical district of Prague, one can see the attention paid to harmonize new useful elements - architectural details related to urban networks and modern furnishings of houses - with the historic character of the city, and only rarely a dissonance between infrastructure and the buildings of the historic nature of the city could be seen.

Acknowledgment - This scientific project was financed within the framework of science research S/WBIŚ/4/2014 funds at Bialystok University of Technology.

\section{References}

1. S. S. Uzunoglu, Procedia Soc. Behav. Sci. 51, 90-98 (2012)

2. P. Gossel, G. Leuthauser, Architektura XX wieku (Taschen, Köln 2010)

3. D.A. Krawczyk, A. Rodero Serrano, K. Gładyszewska-Fiedoruk, J. Civil. Environ. Eng. 8(1), 47-51 (2017)

4. P. Moonena, T. Defraeyec, V. Dorerb, B. Blockend, J. Carmelieta, Frontiers of Arch. Res. 1, 197-228 (2012)

5. A. E. Stamps III, Des. Stud. 20, 83-97 (1999)

6. J. Temelová, N. Dvořáková, Cities 29, 310-317 (2012)

7. E. Lillebye, Landscape Urban Plan. 35, 85-105 (1996)

8. R. Hammersley, T. Westlake, Cities 13, 247-256 (1996)

9. L. Benevolo, Die Geschichte der Stadt, Campus Verlag (Frankfurt-New York 1991)

10. A. Cobbers, Mendelsohn (Taschen, Köln 2007)

11. T. Bardzińska-Bonenberg, On anarchitectonic genealogy of contemporary architectural details, Defining the architectural space, architectural detail today, (Publisher Cracow University of Technology 5-A/1/2012)

12. A. Dal Fabbro, Le forme significanti del progetto (TUAV, Werona 2009) 